\title{
Encapsulation of Lactobacillus acidophilus La-5 and Bifidobacterium Bb-12 by spray drying and evaluation of its resistance in simulated gastrointestinal conditions, thermal treatments and storage conditions
}

\author{
Graciele Lorenzoni Nunes ${ }^{1}$ Mariana Heldt Motta ${ }^{2}$ Alexandre José Cichoski ${ }^{1}$ \\ Roger Wagner ${ }^{1}$ Édson Irineu Muller ${ }^{3}$ Cristiane Franco Codevilla ${ }^{1}$ \\ Cristiane de Bona da Silva ${ }^{2}$ Cristiano Ragagnin de Menezes ${ }^{1^{*}}$ ?
}

${ }^{1}$ Departamento de Ciência e Tecnologia de Alimentos, Centro de Ciências Rurais (CCR), Universidade Federal de Santa Maria (UFSM), 97105-900, Santa Maria, RS, Brasil. E-mail: cristiano.ufsm@gmail.com. .Corresponding author.

${ }^{2}$ Departamento de Farmácia, Centro de Ciências da Saúde (CCS), Universidade Federal de Santa Maria (UFSM), Santa Maria, RS, Brasil. ${ }^{3}$ Departamento de Química, Centro de Ciências Naturais e Exatas (CCNE), Universidade Federal de Santa Maria (UFSM), Santa Maria, RS, Brasil.

ABSTRACT: Lactobacillus acidophillus La-5 (ML) and Bifidobacterium Bb-12 (MB) microparticles were produced at different temperatures by spray dryer. The influence of different temperatures on the viability, encapsulation efficiency, water activity and moisture were evaluated. Microparticles that presented more viability were submitted to thermal resistance, gastrointestinal simulation, storage stability, morphology and particle size analyses. Drying temperature of $130^{\circ} \mathrm{C}$ showed higher encapsulation efficiency, 84.61 and $79.73 \%$ for Lactobacillus acidophillus $(M L)$ and Bifidobacterium Bb-12 (MB) microparticles, respectively. In the evaluation of thermal resistance and gastrointestinal simulation, the microparticles of Lactobacillus acidophillus La-5 (ML) presented higher survival than Bifidobacterium Bb-12 (MB) under these conditions. In storage viability only the Lactobacillus acidophillus La-5 (ML) microparticles remained viable at all evaluated temperatures during the 120 days. The particle sizes reported were 4.85 for Lactobacillus acidophillus La-5 (ML) and 8.75 for Bifidobacterium Bb-12 (MB), being in agreement with the desired values for products obtained by spray dryer. Finally, the Lactobacillus acidophilus La-5 (ML) microparticles were shown to be more resistant under the conditions evaluated in this study.

Key words: spray dryer, viability, probiotics.

Encapsulação de Lactobacillus acidophilus La-5 e Bifidobacterium Bb-12 por spray dryer e avaliação da sua resistência em condições gastrointestinais simuladas, tratamentos térmicos e em condições de armazenamento

RESUMO: Micropartículas de Lactobacillus acidophillus La-5 (ML) e Bifidobacterium Bb-12 (MB) foram produzidas em diferentes temperaturas de secagem no spray dryer. A influência das diferentes temperaturas sobre a viabilidade, eficiência de encapsulação, atividade de água e umidade foram avaliadas. As micropartículas que apresentaram maior viabilidade foram submetidas a análises de resistência térmica, simulação gastrointestinal, estabilidade ao armazenamento, morfologia e tamanho de partícula. A temperatura de secagem de $130^{\circ} \mathrm{C}$ mostrou maior eficiência de encapsulação, 84.61 e 79.73\% para microparticulas de Lactobacillus acidophillus (ML) e Bifidobacterium Bb-12 $(M B)$, respectivamente. Na avaliação da resistência térmica e simulação gastrointestinal as micropartículas de Lactobacillus acidophillus La-5 (ML) apresentaram maior sobrevivência que Bifidobacterium Bb-12 (MB) nestas condições. Na viabilidade ao armazenamento somente as micropartículas Lactobacillus acidophillus La-5 (ML) mantiveram-se viáveis em todas as temperaturas avaliadas durante os 120 dias. Os tamanhos de particula encontrados foram de 4.85 para Lactobacillus acidophillus La-5 (ML) e 8.75 para Bifidobacterium Bb-12 (MB), estando de acordo aos valores desejáveis para produtos obtidos por spray dryer. Por fim, as microparticulas de Lactobacillus acidophilus La-5 (ML) demostraram ser mais resistentes frente as condições avaliadas neste estudo.

Palavras-chave: spray dryer, viabilidade, probióticos.

\section{INTRODUCTION}

Probiotics are live microorganisms, which when consumed in adequate amounts, conferring a health benefit for the host. In this context, in recent years there has been a great deal of interest in its use and application in food especially in fermented dairy products (yogurt, fermented milk and cheese). However, there is also increasing interest for the use of probiotics in non-dairy products such as fruit and vegetable juices, soy and some cereals (FAO/ OMS, 2001; DAS \& GOYAL, 2015; FIJAN, 2014; 
RANADHEERA et al., 2017). Bifidobacterium lactis and Lactobacillus acidophillus are the probiotic bacteria most widely studied and frequently used in food (FELICIO et al., 2016; HOMAYOUNI et al., 2008). RANADHEERA et al. (2015) microencapsulated Lactobacillus acidophilus La5, Bifidobacterium Bb-12 and Propionibacterium jansenii 702 by spray drying in goat's milk. Recently, Kavitek et al. (2018) demonstrated recent developments on encapsulation of lactic acid bacteria as potential starter culture in fermented foods. According to ANAL \& SINGH (2007), the ability of probiotic microorganisms to survive and develop in the host will directly influence their probiotic effects. Therefore, the microorganism that is metabolically stable in the product and survive the passage through the gastrointestinal tract reaching the intestine with high viability will be able to develop its beneficial effects. Application of microencapsulation processes has been studied as an alternative to maintain high viability of these microorganisms (FUNG et al, 2011; KIM et al., 2011). Among different microencapsulation techniques, spray drying is commonly used for its advantages such as low operating costs, high production rates, low moisture content in the final product and possibility of application on an industrial scale (CORCORAN et al., 2004). However, this process requires high temperatures, which may affect the survival of probiotic microorganisms (BOZA et al., 2004). In this sense, optimization of the spray-drying conditions as well as the composition of the encapsulation solution are parameters of great importance in order to achieve high survival of the probiotic microorganisms during this process (CORCORAN et al., 2004; FRITZENFREIRE et al., 2012; RAJAM et al., 2013; SIMPSON et al., 2005).

In this context, the aim of this study was to evaluate the influence of different temperatures by spray drying on the viability, encapsulation efficiency, water activity and moisture of microparticles containing Lactobacillus acidophillus La-5 and Bifidobacterium Bb-12. Subsequently, the microparticles that presented the highest viability and best physical-chemical characteristics were evaluated in relation to their thermal resistance, gastrointestinal simulation and storage stability. In addition, the morphology and particle size were also evaluated.

\section{MATERIALS AND METHODS}

To produce microparticles, the following compounds were used: Gum arabic (CNI, São
Paulo, Brazil); Maltodextrin (Ingredion, São Paulo, Brazil); Tween 80 (Vetec, Rio de Janeiro, Brazil); Glycerol (Vetec, Rio de Janeiro, Brazil), and probiotic culture Lactobacillus acidophilus La-5 and Bifidobacterium Bb-12 obtained by Chr. Hansen from Brazil (Valinhos, São Paulo).

\section{Inoculum}

The Lactobacillus acidophilus La-5 probiotic culture (Chr. Hansen, São Paulo, Brazil) was activated in MRS broth (Himedia Curitiba, Parana, Brazil) and incubated for $15 \mathrm{~h}$ at $37^{\circ} \mathrm{C}$. The Bifidobacterium Bb-12 culture was rehydrated in reconstituted milk (Molico, Nestlé, São Paulo, Brazil) at a concentration of $12 \%$ and incubated for 5 hours at $37^{\circ} \mathrm{C}$. Then, it was centrifuged at $4670 \mathrm{~g}$ for $15 \mathrm{~min}$ and washed in $\mathrm{NaCl}$ solution $(0.85 \%)$. Cells were then suspended in saline to obtain a solution containing about 12 and $10 \log \mathrm{CFU} / \mathrm{g}^{-1}$.

\section{Production of microparticles by spray drying}

Feed solutions were prepared with gum $\operatorname{arabic}(8 \mathrm{~g})$, maltodextrin $(2 \mathrm{~g})$, glycerol $(1.9 \mathrm{~mL})$, tween $80(0.1 \mathrm{~mL})$ containing Lactobacillus acidophilus La-5 (SL) and Bifidobacterium Bb-12 (SB) to a final concentration of $12 \% \mathrm{~m} / \mathrm{v}$. Microencapsulation process was performed in a lab spray dryer (MSD 1.0 Labmaq, Sao Paulo, Brazil). Initially, the feed solutions (SL and SB) were submitted to different drying temperatures, $110,120,130$ and $140^{\circ} \mathrm{C}$. Next, the microparticles produced at the inlet temperature of $130^{\circ} \mathrm{C}$ were chosen to be further evaluated. Different feed solutions, kept stirring, were introduced into the drying chamber using a peristaltic pump with feed rate of $0.48 \mathrm{~L} / \mathrm{h}$, drying air flow rate of $40 \mathrm{~L} / \mathrm{min}$, and air pressure of $0.6 \mathrm{MPa}$. The microparticles (ML and $\mathrm{MB}$ ) were collected at the base of the cyclone, transferred to sterile vials, and stored in a desiccator.

\section{Viable cell count}

Serial dilutions for Lactobacillus acidophilus La-5 and Bifidobacterium Bb-12 were transferred to sterile Petri plates containing MRS agar (Himedia Curitiba, Paraná, Brazil), in triplicate. The MRS agar used for Bifidobacterium $\mathrm{Bb}-12$ was added lithium chloride $(0.1 \%)$ and L-cysteine $(0.05 \%)$, according to manufacturer recommendations $(\mathrm{Chr}$ Hansen, 1999). Plates were incubated at $37^{\circ} \mathrm{C}$ for $72 \mathrm{~h}$ in anaerobic jars with an anaerobic generator (Oxoid, São Paulo, Brazil).

Dilution of the microparticles comprised weighing $1 \mathrm{~g}$ of microparticles followed by the addition of $9 \mathrm{~mL}$ sterile phosphate buffer solution $(\mathrm{pH}$ 
7.5), following the methodology described by SHEU et al. (1993). Results were shown as log colony forming units per gram $\left(\log \mathrm{CFU} / \mathrm{g}^{-1}\right)$.

\section{Efficiency of encapsulation (EE)}

The efficiency of encapsulation (EE) is the survival rate of the microorganisms during the microencapsulation process, calculated according to Eq. (1), as proposed by MARTIN et al. (2013): $E E \%=\left(N / N_{0}\right) \times 100(1)$

Where $\mathrm{N}$ is the number of viable cells (log $\mathrm{CFU} / \mathrm{g}^{-1}$ ) released from the microparticles and $\mathrm{N}_{0}$ is the number of viable cells $\left(\log \mathrm{CFU} / \mathrm{g}^{-1}\right)$ free in the feed solution before the spray-drying process. Viable cell count was performed as described in Section "Viable cell count".

\section{Moisture and Water Activity (Aw)}

Moisture content of the microparticles was determined in an oven at $105^{\circ} \mathrm{C}$ until constant weight, according to the methodology proposed by AOAC (2005). Water activity was measured at $25^{\circ} \mathrm{C}$ using Aqualab 4TE equipment (Decagon Devices, Pullman, WA, USA) after prior stabilization of the samples for $15 \mathrm{~min}$.

\section{Microparticle morphology and size}

Morphology of the microcaparticles was evaluated using an optical microscope (Carl Zeiss Axio Scope. A1, Oberkochen, Germany) equipped with an Axio Cam MRc digital camera (Carl Zeiss) and scanning electronic microscope (SEM; JEOL JM6360, Tokyo, Japan). Distribution of microparticle size was measured using a Mastersizer 3000 (Malvern, Germany), with water as the dispersion medium.

\section{Resistance to heat treatment}

Thermal resistance was assessed as proposed by ZHANG et al. (2015), with some adaptations. Microparticles and free culture (1g) were transferred to $9 \mathrm{ml}$ of peptone water in test tubes. Contents were then subjected to thermal conditions of $72^{\circ} \mathrm{C}$ for 15 seconds and $63^{\circ} \mathrm{C}$ for 30 minutes, after which tubes were immediately cooled by immersion on ice for $10 \mathrm{~min}$. Finally, aliquots were collected and probiotic cultures were counted according to Section "Viable cell count".

Assessment of the survival of encapsulated Lactobacillus acidophilus La-05 and Bifidobacterium Bb-12 exposed to simulated gastrointestinal conditions

The method proposed by MADUREIRA et al. (2011), with some adaptations, was used to submit the microparticles to simulated gastrointestinal conditions. Viability of the bacteria was determined in media simulating the different sections of the gastrointestinal tract, such as esophagus/stomach (addition of pepsin, $\mathrm{pH}$ adjusted to 2.0 for $90 \mathrm{~min}$ ), duodenum (addition of pancreatin and bile salts, $\mathrm{pH}$ adjusted to 5.0 for $20 \mathrm{~min}$ ), and ileum ( $\mathrm{pH}$ adjusted to 7.5 for $90 \mathrm{~min}$ ). Analysis was conducted on a TE 421 Shaker (Tecnal, Piracicaba, SP, Brazil) at a temperature of $37^{\circ} \mathrm{C}$, simulating the temperature of the human body. Finally, aliquots were removed after 90min (esophagus or stomach), 110min (duodenum), or 200min (ileum) to determine the survival of free and microencapsulated Lactobacillus acidophilus La5. Probiotic cultures were counted in MRS medium as described in Section "Viable cell count".

Viability of microparticles during storage at different temperatures

Viability of the microencapsulated microorganisms was determined by enumeration in MRS agar, as described in Section 2.3. Microparticles were examined after storage for $0,15,30,45,60,75$, 90,105 , and 120 days at $25^{\circ} \mathrm{C},-18^{\circ} \mathrm{C}$ and $7^{\circ} \mathrm{C}$.

\section{Statistical analysis}

Data were submitted to analysis of variance (ANOVA) using Statistic version 7.0 software (2004; Statsoft Inc., Tulsa, OK, USA), followed by Tukey's means comparison test at a level of $5 \%$ significance of treatments showing possible significant differences. All experiments were performed in triplicate; data are expressed as means \pm standard deviations.

\section{RESULTS AND DISCUSSION}

Viability, encapsulation efficiency, water activity and moisture of microparticles produced t different drying temperatures

The viability of the microparticles containing Lactobacillus acidophilus La-5 (ML) and Bifidobacterium Bb-12 (MB) produced at the different drying temperatures can be seen in table 1. The air inlet temperature of $140^{\circ} \mathrm{C}$ had a significant effect $(\mathrm{P}<0.05)$ in relation to the other conditions evaluated, presenting the lowest results for viability for both microparticles studied (ML and MB). Temperature of $130^{\circ} \mathrm{C}$ showed the greatest viability for Lactobacillus acidophilus La-5 (ML) and Bifidobacterium Bb-12 (MB) microparticles, but there was no significant difference $(\mathrm{P}<0.05)$ among temperatures of 110,120 and $130^{\circ} \mathrm{C}$. Similar results were reported by BUSTAMANTE et al. (2017) when encapsulating Lactobacillus acidophilus 
Table 1 - Viability, encapsulation efficiency, water activity and moisture of microparticles containg Lactobacillus acidophilus La-5 (ML) and Bifidobacterium Bb-12 (MB) produced at different inlet temperatures in the spray dryer.

\begin{tabular}{|c|c|c|c|c|c|c|}
\hline \multirow[t]{5}{*}{$\begin{array}{l}\text { ML (Lactobacillus } \\
\text { acidophilus La-5) }\end{array}$} & $\begin{array}{l}\text { Initial viability } \\
\log \mathrm{CFU} / \mathrm{g}\end{array}$ & Temperatures inlet & $\begin{array}{l}\text { Post-encapsulation } \\
\text { viability } \log \mathrm{CFU} / \mathrm{g}\end{array}$ & $\begin{array}{c}\text { Encapsulation } \\
\text { efficiency }(\mathrm{EE} \%)\end{array}$ & Water activity & Moisture (\%) \\
\hline & & $110^{\circ} \mathrm{C}$ & $10.18 \pm 0.05^{b}$ & $83.30 \pm 0.28^{a}$ & $0.289 \pm 0.06^{\mathrm{a}}$ & $5.71 \pm 0.10^{\mathrm{a}}$ \\
\hline & $12.22 \pm 0.20^{\mathrm{a}}$ & $120^{\circ} \mathrm{C}$ & $10.22 \pm 0.05^{b}$ & $83.63 \pm 0.33^{\mathrm{a}}$ & $0.275 \pm 0.02^{\mathrm{a}}$ & $5.41 \pm 0.33^{\mathrm{a}}$ \\
\hline & & $130^{\circ} \mathrm{C}$ & $10.34 \pm 0.10^{\mathrm{b}}$ & $84.61 \pm 0.51^{\mathrm{a}}$ & $0.270 \pm 0.05^{\mathrm{a}}$ & $5.26 \pm 0.20^{\mathrm{ab}}$ \\
\hline & & $140^{\circ} \mathrm{C}$ & $9.92 \pm 0.07^{c}$ & $81.17 \pm 0.39^{b}$ & $0.237 \pm 0.11^{\mathrm{b}}$ & $4.60 \pm 0.33^{b}$ \\
\hline \multicolumn{7}{|c|}{-MB (Bifidobacterium Bb-12)--- } \\
\hline & & $110^{\circ} \mathrm{C}$ & $8.19 \pm 0.07^{\mathrm{b}}$ & $77.92 \pm 0.39^{\mathrm{a}}$ & $0.228 \pm 0.07^{\mathrm{a}}$ & $5.34 \pm 0.06^{\mathrm{a}}$ \\
\hline & $10.51 \pm 0.02^{\mathrm{a}}$ & $120^{\circ} \mathrm{C}$ & $8.25 \pm 0.11^{\mathrm{b}}$ & $78.49 \pm 0.55^{\mathrm{a}}$ & $0.213 \pm 0.05^{\mathrm{a}}$ & $4.96 \pm 0.07^{\mathrm{b}}$ \\
\hline & & $130^{\circ} \mathrm{C}$ & $8.38 \pm 0.12^{\mathrm{b}}$ & $79.73 \pm 0.60^{\mathrm{a}}$ & $0.208 \pm 0.09^{\mathrm{a}}$ & $4.83 \pm 0.04^{\mathrm{c}}$ \\
\hline & & $140^{\circ} \mathrm{C}$ & $7.81 \pm 0.15^{\mathrm{c}}$ & $74.31 \pm 0.77^{\mathrm{a}}$ & $0.195 \pm 0.08^{\mathrm{a}}$ & $4.61 \pm 0.04^{\mathrm{d}}$ \\
\hline
\end{tabular}

ML: microparticles produced with $8 \mathrm{~g}$ of gum arabic, $2 \mathrm{~g}$ of maltodextrin, $1.9 \mathrm{~mL}$ of glycerol, $0.1 \mathrm{~mL}$ of tween 80 and Lactobacillus acidophilus La-5; MB: microparticles produced with $8 \mathrm{~g}$ of gum arabic, $2 \mathrm{~g}$ of maltodextrin, $1.9 \mathrm{~mL}$ of glycerol, $0.1 \mathrm{~mL}$ of tween 80 and Bifidobacterium $\mathrm{Bb}-12$. Means followed by the same letter, lowercase in the column, do not differ statistically from each other by the Tukeytest at 5\% significance. Means found in triplicate.

with mucilage extracted from the chia seed at two different spray dryer temperatures $\left(110^{\circ} \mathrm{C}\right.$ and $140^{\circ} \mathrm{C}$ ). These authors reported lower survival of encapsulated Lactobacillus acidophilus at $140^{\circ} \mathrm{C}$. ARSLAN et al. (2015) reported that an increase in the air inlet temperature of the spray dryer resulted in decreased viability and lower survival rates of Saccharomyces cerevisiae var. boulardi. Increase in the inlet temperature of the spray dryer consequently causes an increase in the outlet temperature. PISPAN et al. (2013) explained that an increase in the outlet temperature directly increases the temperature at which the microparticles are exposed. Conversely, a reduction in the outlet temperature results in a longer drying time. Thus, viability losses during the spray drying process can arise from dehydration and high temperatures. These two mechanisms occurring at the same time cause a negative effect on the survival of probiotic microorganisms (PEIGHAMBARDOUST et al., 2011; RIVEROS et al., 2009). The encapsulation efficiency (Table 1) ranged from 81.17 to $84.61 \%$ and 74.31 to $79.73 \%$ for the microparticles containing Lactobacillus acidophilus La-5 (ML) and Bifidobacterium Bb-12 (MB), respectively. Therefore, it is possible to observe that Lactobacillus acidophilus La-5 presented greater resistance on the spray-drying conditions compared to Bifidobacterium Bb-12. RANADHEERA et al. (2015) evaluated viability of Bifidobacterium Bb-12, Lactobacillus acidophilus La-5 and Propionibacterium jansenii encapsulated in spray dryer reported greater loss viability for Bifidobacterium Bb-12. The current study showed greater resistance to the drying conditions used for the Lactobacillus acidophilus (LAC4) culture compared to Bifidobacterium lactis (B01). The highest encapsulation efficiency for both microparticles produced, ML (84.61\%) and MB (79.73\%) was observed at $130^{\circ} \mathrm{C}$. FAVARO-TRINDADE AND GROSSO (2002) and LIAN et al. (2002) reported that different strains of microorganisms may vary in their ability to tolerate the high temperatures imposed during spray drying.

In the evaluation of the effect of different input temperatures on the water activity (Table 1) of Lactobacillus acidophilus La-5 (ML) and Bifidobacterium Bb-12 (MB) microparticles, we observed that the temperature of $140^{\circ} \mathrm{C}$ had a significant influence $(\mathrm{P}<0.05)$, presenting the lowest water activity content for both studied microparticles. Nonetheless, the water activity reported in the different evaluated temperatures for the Lactobacillus acidophilus La-5 (ML) and Bifidobacterium $\mathrm{Bb}-12$ microparticles ranged from 0.195 to 0.289 . Thus, these results are as expected for microparticles dried by spray dryer $(0.150$ to $0.300)$ to ensure their microbiological stability (CORCORAN et al., 2004; ARSLAN et al., 2015).

The microparticles moisture content ranged from $4.60 \%$ to $5.71 \%$ (Table 1 ) and the lowest moisture contents were observed as the inlet temperature of the spray dryer was raised. FERRARI et al. (2012) reported that higher temperatures imply a higher rate of heat transfer to the microparticles, resulting in a higher water evaporation and consequently, low 
moisture contents are obtained. Results obtained in the present research are in accordance with those reported by other authors who recommend that the moisture content should be around $4-5 \%$ to guarantee better storage stability (CHAVEZ \& LEDEBOER, 2007). In this sense, studies have shown that a lower inlet temperature and, consequently output, results in increased post-encapsulation viability; however, this condition may imply greater moisture and water activity, which adversely affects the prolonged storage of powders (PEIGHAMBARDOUST et al., 2011; VESTERLUND et al., 2012). Thus, the relevance of the study of different drying temperatures, not only on the viability of the microorganisms, but also their influence on the physical characteristics of the microparticles is emphasized. MORGAN et al. (2006) reported that spray-drying temperatures are of great importance for the viability of bacteria and need to be optimized individually for every new application. In this context, Lactobacillus acidophilus La-5 (ML) and Bifidobacterium $\mathrm{Bb}-12$ (MB) microparticles produced at $130^{\circ} \mathrm{C}$ were chosen to be evaluated in this study.

\section{Morphology and size of microparticles}

Scanning electron microscopy of Lactobacillus acidophilus La-5 (ML) and Bifidobacterium Bb-12 (MB) microparticles can be observed in figure 1. The microparticles produced presented a rounded shape containing concavities. The same was observed by FAVARO-TRINDADE \& GROSSO (2002) and FRITZEN-FREIRE et al. (2012). These authors reported that these concavities are typical of spray-dried products. Moreover, it is possible to observe that microparticles of Lactobacillus acidophilus La-5 (ML) and Bifidobacterium Bb-12 (MB) presented high porosity (Figure 1a) and ruptures in their structure (Figure 1b). This fact may be related to the low solids concentration $(12 \% \mathrm{~m} / \mathrm{v})$ used in the formulations. Similar results were shown by PINTO et al. (2015) in the production of microparticles containing Bifidobacterium Bb-12 and using a concentration of $10 \% \mathrm{w} / \mathrm{v}$ in combinations with liquid whey, whey retentate, inulin and polydextrose.

The particle size observed for the microparticles of Lactobacillus acidophilus La-5 (ML) and Bifidobacterium Bb-12 (MB) was 4.85 and 8.75 , respectively. RAJAM \& ANANDHARAMAKRISHNAN (2015) reported particle sizes from 6.68 to $23.89 \mu \mathrm{m}$ for microparticles containing Lactobacillus plantarum (MTCC 5422) using oligofructose, whey protein isolate and denatured whey protein isolate at a concentration of $20 \%(\mathrm{w} / \mathrm{v})$. ARSLAN et al. (2015) verified particle sizes that ranged between 8.56 and $21.38 \mu \mathrm{m}$ by encapsulating Saccharomyces cerevisiae var. boulardii using gelatin, gum Arabic, maltodextrin, modified starch,
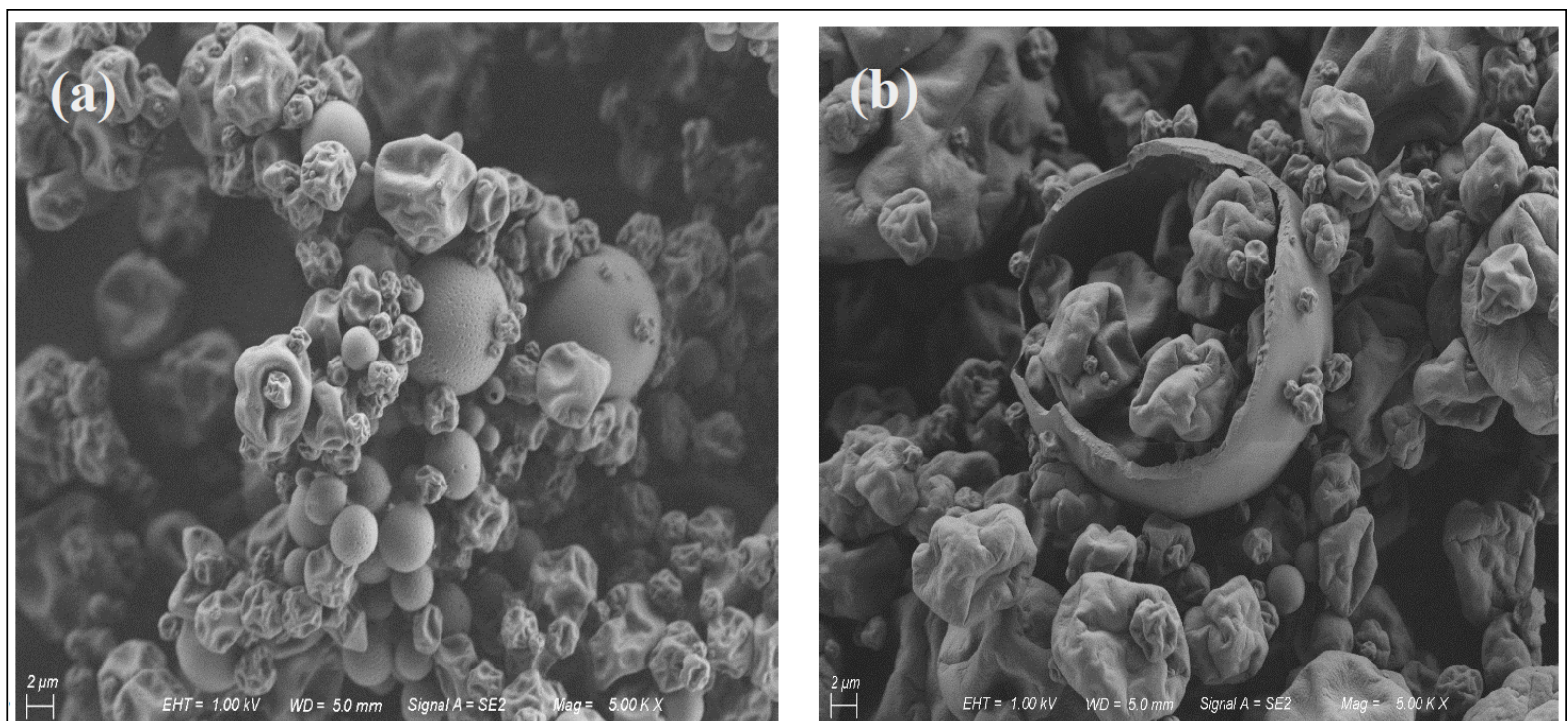

Figure 1 - Micrographs of the microparticles produced with $8 \mathrm{~g}$ of gum arabic, $2 \mathrm{~g}$ of maltodextrin, $1.9 \mathrm{~mL}$ of glycerol, $0.1 \mathrm{~mL}$ of tween 80 and Lactobacillus acidophilus La-5 (ML) e microparticles produced with $8 \mathrm{~g}$ of gum arabic, $2 \mathrm{~g}$ of maltodextrin, $1.9 \mathrm{~mL}$ of glycerol, $0.1 \mathrm{~mL}$ of tween 80 and Bifidobacterium Bb-12 (MB). 
whey protein concentrate and pea protein isolate as encapsulating agents. Smaller particle sizes shown in the present research may be related to the different filmforming and gelling properties of the materials used in the microencapsulation process. In addition, according to KUROZAWA et al. (2009), higher concentrations of encapsulating agents in the feed solution promote an increase in particle size. However, it is worth mentioning that microparticles obtained by spray dryer presented a desirable size, once that smaller particles are preferred to ensure homogeneity and quality when applied to food (BURGAIN et al., 2011).

\section{Resistance of microparticles to heat treatment}

The microparticles of Lactobacillus acidophilus La-5 (ML) and Bifidobacterium Bb12 (MB) were evaluated to the heat treatments of $63^{\circ} \mathrm{C} / 30 \mathrm{~min}$ and $72^{\circ} \mathrm{C} / 15 \mathrm{~s}$ (Table 2). The microparticles of Lactobacillus acidophilus La-5 (ML) and Bifidobacterium $\mathrm{Bb}-12(\mathrm{MB})$ presented reductions of 1.91 and 1.93 , at $63^{\circ} \mathrm{C} / 30 \mathrm{~min}$ and 1.36 and 1.42 at $72^{\circ} \mathrm{C} / 15 \mathrm{~s}$, respectively. Thus, Lactobacillus acidophilus La-5 (ML) microparticles presented higher resistance to the thermal treatments studied. FAVARO-TRINDADE \& GROSSO (2002) and LIAN et al. (2002) have shown in previous studies that different strains of microorganisms can vary their ability to resist high temperatures. Bifidobacteria are known to be more susceptible to high temperatures than lactobacilus (DOLEYRES \& LACROIX, 2005). However, it is noteworthy that for both thermal treatments studied, all viable cell counts of Lactobacillus acidophilus La-5 (ML) and Bifidobacterium Bb-12 (MB) microparticles were superior than $6 \log \mathrm{CFU} / \mathrm{g}^{-1}$.

Regarding the different applied thermal treatments, the higher temperature and the shorter time $\left(72^{\circ} \mathrm{C} / 15 \mathrm{~s}\right)$ resulted in higher survival for the Lactobacillus acidophilus La-5 (ML) and Bifidobacterium Bb-12 (MB) microparticles. These results are in accordance with those reported by ZHANG, et al. (2015) and NUNES et al. (2017), who reported better survival of Lactobacillus salivarius NRR B-30514 and Lactobacillus acidophilus La-5 encapsulated by the emulsion and spray drying methods, respectively, when subjected to heat treatment at $72^{\circ} \mathrm{C} / 15 \mathrm{~s}$ in relative to $63^{\circ} \mathrm{C} / 30 \mathrm{~min}$.

\section{Exposure of microparticles to simulated gastrointestinal conditions}

Table 3 shows viable cell counts of Lactobacillus acidophilus La-5 (ML) and Bifidobacterium Bb-12 (MB) microparticles exposed to simulated gastrointestinal conditions. After $90 \mathrm{~min}$ incubation in the presence of a pepsin solution and $\mathrm{pH}$ adjusted to 2.0 (simulated esophagus/stomach), there was significantly decreased $(\mathrm{P}<0.05)$ of Lactobacillus acidophilus La-5 (ML) and Bifidobacterium Bb-12 (MB) microparticles compared to the initial count of 3.58 and 2.85log cycles, respectively. HOLKEN et al. (2016) and NUNES et al. (2017) verified a similar behaviour when encapsulating Bifidobacterium Bb-12 by emulsification/internal gelation and Lactobacillus acidophillus by spray drying, respectively. These authors explained that this reduction in log cycles does not necessarily imply a loss of viability, since the microparticles should not have ruptured at a $\mathrm{pH}$ value 2.0. Subsequently, when the microparticles are in contact with bile salts and pH 5.0 (section of the gastrointestinal tract comprising the duodenum), it was observed an increased number of viable cells (Table 4). Similar results were reported by HOLKEM et al. (2016), NUNES et al. (2017) and RAJAM et al. (2013). The increase in viable cell count under these conditions probably resulted from a recovery of the sub-injured cells (PICOT \& LACROIX, 2004). In the

Table 2 - Effect of heat treatments on the viability of microparticles containg Lactobacillus acidophilus La-5 (ML) and Bifidobacterium $\mathrm{Bb}-12(\mathrm{MB})$ produced at inlet temperature of $130^{\circ} \mathrm{C}$ in the spray dryer.

\begin{tabular}{lcc}
\hline Heat treatments & ML (Lactobacillus acidophilus La-5) & MB (Bifidobacterium Bb-12) \\
Initial count log CFU/g & $10.34 \pm 0.10^{\mathrm{aA}}$ & $8.38 \pm 0.12^{\mathrm{aB}}$ \\
$63^{\circ} \mathrm{C} / 30 \mathrm{~min}$ & $8.43 \pm 0.03^{\mathrm{cA}}$ & $6.45 \pm 0.10^{\mathrm{cB}}$ \\
$72^{\circ} \mathrm{C} / 15 \mathrm{~s}$ & $8.98 \pm 0.15^{\mathrm{bA}}$ & $6.96 \pm 0.17^{\mathrm{bB}}$ \\
\hline
\end{tabular}

ML: microparticles produced with $8 \mathrm{~g}$ of gum arabic, $2 \mathrm{~g}$ of maltodextrin, $1.9 \mathrm{~mL}$ of glycerol, $0.1 \mathrm{~mL}$ of tween 80 and Lactobacillus acidophilus La-5; MB: microparticles produced with $8 \mathrm{~g}$ of gum arabic, $2 \mathrm{~g}$ of maltodextrin, $1.9 \mathrm{~mL}$ of glycerol, $0.1 \mathrm{~mL}$ of tween 80 and Bifidobacterium Bb-12. Means followed by the same letter, lowercase in the column and upper case in the row, do not differ statistically from each other by the Tukey test at 5\% significance. Means found in triplicate. 
Table 3 - Viability of microparticles containing Lactobacillus acidophilus La-5 (ML) and Bifidobacterium Bb-12 (MB) produced at inlet temperature of $130^{\circ} \mathrm{C}$ in the spray dryer against simulated gastrointestinal.

\begin{tabular}{lcc}
\hline & ML (Lactobacillus acidophilus La-5) & MB (Bifidobacterium Bb-12) \\
Initial count log CFU/g & $10.34 \pm 0.10^{\mathrm{aA}}$ & $8.38 \pm 0.12^{\mathrm{aB}}$ \\
Esophagus/stomach 90min/pH 2,0 & $6.76 \pm 0.07^{\mathrm{dA}}$ & $5.53 \pm 0.06^{\mathrm{cB}}$ \\
Duodenum 20min/pH 5,0 & $7.06 \pm 0.09^{\mathrm{cA}}$ & $5.69 \pm 0.05^{\mathrm{cB}}$ \\
Ileum 90min/pH 7,5 & $8.62 \pm 0.08^{\mathrm{bA}}$ & $6.34 \pm 0.06^{\mathrm{bB}}$ \\
\hline
\end{tabular}

ML: microparticles produced with $8 \mathrm{~g}$ of gum arabic, $2 \mathrm{~g}$ of maltodextrin, $1.9 \mathrm{~mL}$ of glycerol, $0.1 \mathrm{~mL}$ of tween 80 and Lactobacillus acidophilus La-5; MB: microparticles produced with $8 \mathrm{~g}$ of gum arabic, $2 \mathrm{~g}$ of maltodextrin, $1.9 \mathrm{~mL}$ of glycerol, $0.1 \mathrm{~mL}$ of tween 80 and Bifidobacterium Bb-12. Means followed by the same letter, lowercase in the column and upper case in the row, do not differ statistically from each other by the Tukey test at $5 \%$ significance. Means found in triplicate.

last section of the simulated gastrointestinal tract, the ileum ( $\mathrm{pH} 7.5$ ), the microparticles of Lactobacillus acidophilus La-5 (ML) and Bifidobacterium Bb12 (MB) continued to show a significant increase $(\mathrm{P}<0.05)$ in the number of viable cells (Table 3 ). As the $\mathrm{pH}$ was rising, the number of bacterial cells was increasing. The acid conditions of the stomach cause a dormant state in the bacterial cells, as the $\mathrm{pH}$ goes up they regain their growth (MOUMITA et al., 2017). The microparticles of Lactobacillus acidophilus La-5 (ML) and Bifidobacterium Bb-12 (MB) after exposure to simulated gastrointestinal tract conditions presented reductions of 1.72 and $2.04 \log$ cycles, respectively. Therefore, the Lactobacillus acidophilus La-5 (ML) microparticles were more resistant to simulated gastrointestinal conditions than Bifidobacterium Bb-12 (MB). These results differ from those reported by PEDROSO et al. (2012) who reported greater gastrointestinal survival for Bifidobacterium lactis compared to Lactobacillus acidophilus. According to GOMES \& MALCATA (1999) and KÕLL et al. (2008), there is a variation in the ability of Bifidobacterium and Lactobacillus acidophilus to resist acid and bile conditions. These authors further reported that these properties are specific to strains and species.

\section{Stability of microparticles during storage at different temperatures}

Table 4 shows the viability of Lactobacillus acidophilus La-5 (ML) and Bifidobacterium Bb-12 (MB) microparticles at room temperature $\left(25^{\circ} \mathrm{C}\right)$, below freezing $\left(-18^{\circ} \mathrm{C}\right)$ and under refrigeration $\left(7^{\circ} \mathrm{C}\right)$. Room temperature $\left(25^{\circ} \mathrm{C}\right)$ was the most damaging to the viability of Lactobacillus acidhopilus La-5 (ML) and Bifidobacterium Bb-12 (MB) microparticles, promoting reductions after 120 days' storage between 3.82 and 3.51logs $\mathrm{CFU} / \mathrm{g}^{-1}$. HUANG et al. (2017) microencapsulated by spray drying Lactobacillus casei BL23 and Propionibacterium freudenreichii TG P20 and verified that storage at room temperature $\left(25^{\circ} \mathrm{C}\right)$ resulted in greater viability loss. KOTULA (2008) reported that storage of probiotic powders above refrigeration temperatures increases rates of bacterial metabolism, which can lead to the accumulation of toxic residues and lead to a reduction in viability.

For freezing and refrigeration temperatures, microparticles presented losses of 2.81 and $2.22 \mathrm{log}$ cycles for Lactobacillus acidophilus La-5 (ML) and 2.42 and 2.12 for Bifidobacterium Bb-12 (MB), respectively. Thus, the refrigeration temperature promoted the greatest viability during storage for 120 days for both studied microparticles. OLIVEIRA et al. (2007) showed that L. acidophilus exhibited greater viability at a storage temperature of $7^{\circ} \mathrm{C}$, thus reporting similar results. Among microparticles of Lactobacillus acidophilus La-5 (ML) and Bifidobacterium Bb-12 (MB), it is possible to observe that for the different evaluated temperatures, Bifidobacterium Bb-12 (MB) presented the smallest reductions during the 120 days of storage. However, considering the minimum level of $10^{6} \operatorname{logs} \mathrm{CFU} / \mathrm{g}^{-1}$ (TALWALKAR et al., 2004), Bifidobacterium Bb12 (MB) microparticles had a shelf life of only 60 days at $25^{\circ} \mathrm{C}$ and 105 days at $-18^{\circ} \mathrm{C}$ while the Lactobacillus acidophilus La-5 (ML) microparticles remained viable throughout the storage period at all studied temperatures. Similar results were reported by PEDROSO et al. (2012) who microencapsulated Bifidobacterium lactis and Lactobacillus acidophilus using spray-chilling. However, BUSTAMANTE et al. (2017) found greater viability for Bifidobacterium infantis in comparison to Lactobacillus plantarum incorporated in instant juice powder stored at $4{ }^{\circ} \mathrm{C}$ for 45 days. According to MARTIN et al. (2015) different 
Table 4 - Effect of room temperature $\left(25^{\circ} \mathrm{C}\right)$, freezing $\left(-18^{\circ} \mathrm{C}\right)$, and refrigeration $\left(7^{\circ} \mathrm{C}\right)$ on the viability of microparticles containing Lactobacillus acidophilus La-5 (ML) and Bifidobacterium Bb-12 (MB) produced at inlet temperature of $130{ }^{\circ} \mathrm{C}$ in the spray dryer during storage for 120 days.

\begin{tabular}{|c|c|c|}
\hline Temperature & \multicolumn{2}{|c|}{--Room $\left(25^{\circ} \mathrm{C}\right)$} \\
\hline Treatments Time (Days) & ML (Lactobacillus acidophilus La-5) & MB (Bifidobacterium Bb-12) \\
\hline 0 & $9.92 \pm 0.10^{\mathrm{aA}}$ & $8.25 \pm 014^{\mathrm{aB}}$ \\
\hline 15 & $8.94 \pm 0.02^{\mathrm{bA}}$ & $7.79 \pm 0.02^{\mathrm{bB}}$ \\
\hline 30 & $8.68 \pm 0.08^{\mathrm{cA}}$ & $7.23 \pm 0.08^{\mathrm{cB}}$ \\
\hline 45 & $8.16 \pm 0.15^{\mathrm{dA}}$ & $6.82 \pm 0.15^{\mathrm{dB}}$ \\
\hline 60 & $7.86 \pm 0.05^{\mathrm{eA}}$ & $6.37 \pm 0.06^{\mathrm{eB}}$ \\
\hline 75 & $7.15 \pm 0.09^{\mathrm{fA}}$ & $5.99 \pm 0.10^{\mathrm{efB}}$ \\
\hline 90 & $6.63 \pm 0.06^{\mathrm{gA}}$ & $5.75 \pm 0.12^{\mathrm{fB}}$ \\
\hline 105 & $6.41 \pm 0.08^{\mathrm{gA}}$ & $5.34 \pm 0.13^{\mathrm{gB}}$ \\
\hline 120 & $6.10 \pm 0.10^{\mathrm{hA}}$ & $4.74 \pm 0.13^{\mathrm{hB}}$ \\
\hline Temperature & \multicolumn{2}{|c|}{ - } \\
\hline Treatments Time (Days) & ML (Lactobacillus acidophilus La-5) & MB (Bifidobacterium Bb-12) \\
\hline 0 & $9.92 \pm 0.10^{\mathrm{aA}}$ & $8.25 \pm 014^{\mathrm{aB}}$ \\
\hline 15 & $8.96 \pm 0.08^{\mathrm{bA}}$ & $7.92 \pm 0.03^{\mathrm{bB}}$ \\
\hline 30 & $8.68 \pm 0.07^{\mathrm{cA}}$ & $7.59 \pm 0.02^{\mathrm{cB}}$ \\
\hline 45 & $8.26 \pm 0.03^{\mathrm{dA}}$ & $7.23 \pm 0.08^{\mathrm{dB}}$ \\
\hline 60 & $7.95 \pm 0.06^{\mathrm{eA}}$ & $6.93 \pm 0.10^{\mathrm{eB}}$ \\
\hline 75 & $7.65 \pm 0.04^{\mathrm{fA}}$ & $6.77 \pm 0.04^{\mathrm{eB}}$ \\
\hline 90 & $7.43 \pm 0.10^{\mathrm{fA}}$ & $6.43 \pm 0.09^{\mathrm{fB}}$ \\
\hline 105 & $7.23 \pm 0.11^{\mathrm{gA}}$ & $6.12 \pm 0.12^{\mathrm{gB}}$ \\
\hline 120 & $7.11 \pm 0.10^{\mathrm{hA}}$ & $5.83 \pm 0.12^{\mathrm{gB}}$ \\
\hline Temperature & \multicolumn{2}{|c|}{ 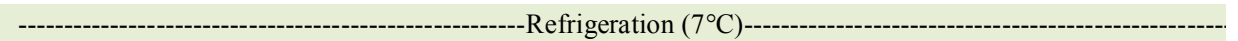 } \\
\hline Treatments Time (Days) & ML (Lactobacillus acidophilus La-5) & MB (Bifidobacterium Bb-12) \\
\hline 0 & $9.92 \pm 0.10^{\mathrm{aA}}$ & $8.25 \pm 014^{\mathrm{aB}}$ \\
\hline 15 & $9.35 \pm 0.14^{\mathrm{bA}}$ & $8.10 \pm 0.08^{\mathrm{aB}}$ \\
\hline 30 & $9.01 \pm 0.03^{\mathrm{cA}}$ & $7.80 \pm 0.09^{\mathrm{bB}}$ \\
\hline 45 & $8.91 \pm 0.04^{\mathrm{cA}}$ & $7.56 \pm 0.09^{\mathrm{bB}}$ \\
\hline 60 & $8.67 \pm 0.05^{\mathrm{dA}}$ & $7.18 \pm 0.14^{\mathrm{cB}}$ \\
\hline 75 & $8.38 \pm 0.09^{\mathrm{eA}}$ & $6.85 \pm 0.03^{\mathrm{dB}}$ \\
\hline 90 & $8.12 \pm 0.10^{\mathrm{fA}}$ & $6.58 \pm 0.06^{\mathrm{eB}}$ \\
\hline 105 & $7.89 \pm 0.12^{\mathrm{fA}}$ & $6.22 \pm 0.08^{\mathrm{fB}}$ \\
\hline 120 & $7.56 \pm 0.11^{\mathrm{gA}}$ & $6.08 \pm 0.08^{\mathrm{fB}}$ \\
\hline
\end{tabular}

ML: microparticles produced with $8 \mathrm{~g}$ of gum arabic, $2 \mathrm{~g}$ of maltodextrin, $1.9 \mathrm{~mL}$ of glycerol, $0.1 \mathrm{~mL}$ of tween 80 and Lactobacillus acidophilus La-5; MB: microparticles produced with $8 \mathrm{~g}$ of gum arabic, $2 \mathrm{~g}$ of maltodextrin, $1.9 \mathrm{~mL}$ of glycerol, $0.1 \mathrm{~mL}$ of tween 80 and Bifidobacterium Bb-12. Means followed by the same letter, lowercase in the column and upper case in the row, do not differ statistically from each other by the Tukey test at $5 \%$ significance. Means found in triplicate.

probiotic strains present distinct abilities to resist environmental conditions such as oxygen, $\mathrm{pH}$, light and temperature. In addition, the conditions of the microencapsulation process are of great importance for the microorganisms to remain viable during their storage (OLIVEIRA et al., 2007).

\section{CONCLUSION}

The inlet temperature of $130^{\circ} \mathrm{C}$ in the spray dryer promoted the highest viability and encapsulation efficiency for the Lactobacillus acidophilus La-5 (ML) and Bifidobacterium Bb-12 (MB) microparticles, submitted to different drying temperatures. The Lactobacillus acidophilus La-5 (ML) microparticles showed greater viability when exposed to thermal treatments and gastrointestinal simulation. In the storage viability for 120 days, the refrigeration temperature $\left(7^{\circ} \mathrm{C}\right)$ was the one that maintained the highest viability for both produced microparticles. However, only the microparticles of Lactobacillus acidophilus La-5 (ML) maintained their 
counts higher than $6 \log \mathrm{CFU} / \mathrm{g}^{-1}$ at all temperatures that were studied $\left(25,-18\right.$ and $\left.7^{\circ} \mathrm{C}\right)$. Bifidobacterium Bb-12 (MB) microparticles had a 60 days shelf life at $25^{\circ} \mathrm{C}$ and 105 days at $-18^{\circ} \mathrm{C}$, thus demonstrating that they could be applied to food products with shorter shelf life. Among the studied microparticles, Lactobacillus acidophilus La-5 (ML) showed greater viability and resistance under the conditions evaluated in this research or study.

\section{ACKNOWLEDGEMENTS}

The authors are grateful to the Coordenação de Aperfeiçoamento de Pessoal de Nível Superior (CAPES) by the scholarship granted to the first author and the availability of use of the laboratories in the Departments of Chemistry and Farmacy in Universidade Federal de Santa Maria.

\section{DECLARATION OF CONFLICTING INTERESTS}

The authors declare no conflict of interest. The founding sponsors had no role in the design of the study; in the collection, analyses, or interpretation of data; in the writing of the manuscript, and in the decision to publish results.

\section{REFERENCES}

ANAL, A. K.; SINGH, H. Recent advances in microencapsulation of probiotics for industrial applications and targeted delivery. Trends in Food Science \& Technology, v. 18, p. 240-251, 2007. Available from: <https://www.sciencedirect.com/science/ article/pii/S0924224407000350>. Accessed: Nov. 03, 2017. doi: 10.1016/j.tifs.2007.01.004

ARSLAN, S. et al. Microencapsulation of probiotic Saccharomyces cerevisiae var. boulardii with diferente wall material by spray drying. LWT- Food Science and Technology, v. 63, p. 685-690, 2015. Available from: <https://www.sciencedirect.com/science/ article/pii/S0023643815001875>. Accessed: Nov. 10, 2017. doi: 10.1016/j.lwt.2015.03.034.

Association of Official Analytical Chemists - AOAC. 2005. Official methods of analysis of the association analytical chemists (18th. Edition). Maryland, USA.

BOZA, Y. et al. Effect of spray-drying on the quality of encapsulated cells of Beijerinckia sp. Process Biochemistry, v. 39, p. 1275-1284, 2004. Available from: <https://www.sciencedirect. com/science/article/pii/S0032959203002577>. Accessed: Oct. 25, 2017. doi: 10.1016/j.procbio.2003.06.002.

BURGAIN, J. et al. Encapsulation of probiotic living cells: from laboratory scale to industrial applications. Journal of Food Engineering, v. 104, p. 467-483, 2011. Available from: <https:// www.sciencedirect.com/science/article/pii/S026087741000631X>. Accessed: Nov. 15, 2017. doi: 10.1016/j.jfoodeng.2010.12.031.

BUSTAMANTE, M. et al. Effective Lactobacillus plantarum and Bifidubaterium infantis encapsulated with chia seed (Salvia Hispanica L.) and flax seed (Linun Usitatissimum L.) mucilage and soluble protein by spray drying. Food Chemistry, v. 1, n. 216, p. 97-105, 2017. Available from: <https://www.ncbi.nlm.nih. gov/pubmed/27596397>. Accessed: Nov. 11, 2017. doi: 10.1016/j. foodchem.2016.08.019.

CHAVEZ, B. E.; LEDEBOER, A. M. Drying of probiotics: optimixation of formulation and process to enchance storage survival. Drying Technology, v. 25, p. 1193-1201, 2007. Available from: <http://www.tandfonline.com/doi/ abs/10.1080/07373930701438576>. Accessed: Nov. 11, 2017. doi: $10.1080 / 07373930701438576$.

CORCORAN, B. M., et al. Comparative survival of probiotic lactobacilli spray dried in the presence of prebiotic substances. Journal of Applied Microbiology, v, 96, p. 1024-1039, 2004. Availabe from: $<$ https://www.ncbi.nlm.nih.gov/pubmed/15078519>. Accessed: Nov. 13, 2016. doi: 10.1111/j.1365-2672.2004.02219.x.

DAS, D.; GOYAL, A. Antioxidant activity and g-aminobutyric acid (GABA) producing ability of probiotic Lactobacillus plantarum DM5 isolated from Marcha of Sikkim. LWT-Food Science and Technology, v. 61, p. 263-268, 2015. Available from: <http:// www.sciencedirect.com/science/article/pii/S0023643814007166>. Accessed: Nov. 08, 2017. doi: 10.1016/j.lwt.2014.11.013.

DOLEYRES, Y.; LACROIX, C. Technologies with free and immobilised cells for probiotic bifidobacteria production and protection. International Dairy Journal, v. 15, p. 973-988, 2005. Available from: <https://www.sciencedirect.com/science/ article/pii/S0958694605000063>. Accessed: Nov.05, 2017. doi: 10.1016/j.idairyj.2004.11.014.

FAVARO-TRINDADE; GROSSO. Microencapsulation of $L$. acidophilus (La-05) and B. lactis (Bb-12) and evaluation of their survival at the $\mathrm{pH}$ values of the stomach and in bile. Journal of Microencapsulation, v. 19, n. 4, p. 485-494, 2002. Available from: $<$ https://www.ncbi.nlm.nih.gov/pubmed/12396385>. Accessed: Apr. 11, 2018. doi. 10.1080/02652040210140715.

FELICIO, T. L. et al. Physico-chemical changes during storage and sensory acceptance of low sodium probiotic minas cheese added with arginine. Food Chemistry, v. 196, p. 628-637, 2016. Available from: $<$ https://www.ncbi.nlm.nih.gov/pubmed/26593536>. Accessed: Dec. 11, 2017. doi: 10.1016/j.foodchem.2015.09.102.

FERRARI, C. C., et al. Spray drying of blackberry pulp using maltodextrin as carrier agent. Brazilian Journal Food Technology, v. 15, p. 157-165, 2012. Available from: <http://www.scielo.br/pdf/ bjft/v15n2/aop_1411.pdf $>$. Accessed: Nov. 10, 2017. doi: 10.1590/ S1981-67232012005000009.

FIJAN, S. 2014. Microorganisms with claimed probiotic properties: An overview of recent literature. International Journal of Environmental Research and Public Health, v. 11, p. 4745-4767. Available from: <https://www.ncbi.nlm.nih.gov/pmc/ articles/PMC4053917/>. Accessed: Dec. 07, 2017. doi: 10.3390/ ijerph110504745.

FRITZEN-FREIRE, C. B. et al. Microencapsulation of bifidobacteria by spray drying in the presence of prebiotics. Food Research International, v. 45, p. 306-312, 2012. Available from: <https:// www.sciencedirect.com/science/article/pii/S0963996911005539>. Accessed: Nov. 18, 2017. doi: 10.1016/j.foodres.2011.09.020.

FUNG, W. Y. et al. Agrowaste-based nanofibers as a probiotic encapsulant: fabrication and characterization. Journal of Agricultural 
and Food Chemistry, v. 59, p. 8140-8147, 2011. Available from: $<$ https://www.ncbi.nlm.nih.gov/pubmed/21711050>. Accessed: Nov. 12, 2017. doi: 10.1021/jf2009342.

GOMES, A. M. P.; MALCATA, F. X. Bifidobacterium spp. and Lactobacillus acidophilus: biological, biochemical, technological and therapeutical properties relevant for use as probiotics. Trends in Food Science \& Technology, v. 10, p. 139-157, 1999. Available from: <https:/www.sciencedirect.com/science/article/ pii/S0924224499000333>. Accessed: Dec. 14, 2017. doi: 0.1016/ S0924-2244(99)00033-3.

HOLKEN, A. T. et al. Development and characterization of alginate microcapsules containing Bifidubacterium BB12 produced by emulsification/internal gelation followed by freeze drying. LWT - Food Science and Technology, 71, 302-308, 2016. Available from: <https://www.sciencedirect.com/science/ article/pii/S0023643816301967>. Accessed: Dec. 11, 2017. doi: 10.1016/j.lwt.2016.04.012.

HOMAYOUNI, A. et al. Effect of microencapsulation and resistant starch on the probiotic survival and sensory properties of synbiotic ice cream. Food Chemistry, v. 111, p. 50-55, 2008. Available from: $<$ https://www.sciencedirect.com/science/ article/pii/S0308814608003245>. Accessed: Dec. 02, 2017. doi: 10.1016/j.foodchem.2008.03.036.

HUANG, S. et al. Spray Drying of probiotics and other food-grade bacteria: A review. Trendes in Food Science \& Techonology, v. 63, p. 1-17, 2017. Available from: <https://www.sciencedirect com/science/article/pii/S0924224416303247>. Accessed: Dec. 18, 2017. doi: $10.1016 /$ j.tifs.2017.02.007.

KÕLL, P. et al. Characterization of oral lactobacillus as potential probiotics for oral health. Oral Microbiology Immunology, v. 23, p. 139-47. Available from: <https://www.ncbi.nlm.nih.gov/ pubmed/18279182>. Accessed: Nov. 10, 2017. doi: 10.1111/j.1399302X.2007.00402.x

KAVITEK et al. Recent developments on encapsulation of lactic acid bacteria as potential starter culture in fermented foods - A review. Food Bioscience, v. 21, p. 34-44, 2018. Available from: <https:// www.sciencedirect.com/science/article/pii/S2212429217302961>. Accessed: Apr. 11, 2018.

KOTUlA, L. U. 2008. Application of a Propionibacterium jensenii 702 for human consumption. Australia: University of Newcastle, Ph.D., thesis.

KUROZAWA, L. E. et al. Effect of maltodextrin and gum arabic on water sorption and glass transition temperature of spray dried chicken meat hydrolysate protein. Journal of Food Engineering, v. 91, p. 287-296, 2009. Available from: <https://www.sciencedirect. com/science/article/pii/S0260877408004470>. Accessed: Dec. 05, 2017. doi: 10.1016/j.jfoodeng.2008.09.006.

LIAN, W. C.; et al. Survival of bifidobacteria after spray drying. International Journal Food Microbiology, v. 74, p. 79-86, 2002. Available from: $<$ http://www.sciencedirect.com/science/article/pii/ S0168160501007334>. Accessed: Dec. 14, 2017. doi: 10.1016/ S0168-1605(01)00733-4.

MADUREIRA, A. R. et al. Protective effect of whey cheese matrix on probiotic strains exposed to simulated gastrointestinal conditions. Food Research International, n. 44, p. 465-470, 2011. Available from: <https://www.sciencedirect.com/science/
article/pii/S0963996910003182>. Accessed: Nov. 30, 2017. doi: 10.1016/j.foodres.2010.09.010.

MARTIN, M. J. et al. Effect of unmodified starch on viability of alginate-encapsulated Lactobacillus fermentum CECT5716. LWT - Food Science and Technology, v. 53, p.480-486, 2013. Available from: <https://www.sciencedirect.com/science/article/pii/ S002364381300114X $>$. Accessed: Oct. 21, 2017. doi: 10.1016/j. lwt.2013.03.019.

MARTIN, M. J. et al. Microencapsulation of bacteria: A review of different technologies and their impact on the probiotic effects. Innovative Food Science and Technologies, v. 27, p. 15-25, 2015. Available from: <https://www.sciencedirect.com/science/ article/pii/S146685641400160X>. Accessed: Nov. 24, 2017. doi: 10.1016/j.ifset.2014.09.010

MORGAN, C. A. et al. Preservation of micro-organisms by drying: a review. Journal Microbiology Methods, 66, 183193, 2006. Available from: <https://www.ncbi.nlm.nih.gov/ pubmed/16632005>. Accessed: Oct. 19, 2017. doi: 10.1016/j. mimet.2006.02.017.

MOUMITA, S. et al. Evaluation of the viability of free and encapsulated lactic acid bacteria using in-vitro gastro intestinal model and survivability studies of symbiotic microcapsules in dry food matrix during storage. LWT- Food Science and Technology, v. 77, p. 40-477, 2017. Available from: <http://www.sciencedirect. com/science/article/pii/S0023643816307666>. Accessed: Dec. 10, 2017. doi: 10.1016/j.lwt.2016.11.079.

NAG, A. et al. Microencapsulation of probiotic bacteria using $\mathrm{pH}-$ induced gelation of sodium caseinate and gellan gum. International Dairy Journal, v. 21, p. 247-253, 2011. Available from: <http:// www.sciencedirect.com/science/article/pii/S0958694610002505>. Accessed: Dec. 12, 2017. doi: 10.1016/j.idairyj.2010.11.002.

NUNES, G. L. et al. Inulin, hi-maize, and trehalose as thermal protectants for increasing viability of Lactobacillus acidophilus encapsulated by spray drying. LWT- Food Science and Technology, v. 89, p. 128-133, 2017. Available from: <https:// www.sciencedirect.com/science/article/pii/S0023643817307703>. Accessed: Dec. 12, 2017. doi: 10.1016/j.lwt.2017.10.032.

OLIVEIRA, A. C. et al. Microencapsulation of B. lactis (BI 01) and L. acidophilus (LAC 4) by complex coacervation followed by spouted-bed drying. Drying Technology, v. 25, p. $1687-$ 1693, 2007. Available from: <http://www.tandfonline.com/doi/ abs/10.1080/07373930701590939>. Accessed: Dec. 15, 2017. doi: $10.1080 / 07373930701590939$.

PEDROSO, D. L. et al. Protection of Bifidobacterium lactis and Lactobacillus acidophilus by microencapsulation using spray-chilling. International Dairy Journal, v. 26, p.127-132, 2012. Available from: <https://www.sciencedirect.com/science/ article/pii/S0958694612001021>. Accessed: Nov. 26, 2017. doi: 10.1016/j.idairyj.2012.04.008.

PEIGHAMBARDOUST, S. H. et al. Application of spray drying for preservation of latic acid starter cultures: a review. Trends in Food Science \& Technology, v. 22, p. 215-224, 2011. Available from: $<$ https:// www.sciencedirect.com/science/article/pii/S0924224411000100>. Accessed: Nov. 19, 2017. doi: 10.1016/j.tifs.2011.01.009.

PINTO, S. S. et al. Influence of microencapsulation with sweet whey and prebiotic on the survival of Bifidobacterium BB-12 under 
simulated gastrointestinal conditions and heat treatments. LWT- Food Science and Technology, 1004-1009, 2015. Available from: $<\mathrm{http}: /$ www.sciencedirect.com/science/article/pii/S0023643815300372>. Accessed: Dec. 13, 2017. doi: 10.1016/j.lwt.2015.07.020.

PISPAN, S. et al. Comparison of cell survival rates of E. coli K12 and L. acidophilus undergoing spray drying. Food and Bioproducts Processing, v. 91, p. 362-369, 2013. Available from: <http://www.sciencedirect.com/science/article/ pii/S0960308513000060>. Accessed: Dec. 13, 2017. doi: 10.1016/j.fbp.2013.01.005.

RAJAM, R. P. et al. Effect of whey protein-alginate wall systems on survival of microencapsulated Lacotobacillus plantarum in simulated gastrointestinal conditions. Journal of Functional Foods, v. 4, p. 891-898, 2013. Available from: <https://www. sciencedirect.com/science/article/pii/S1756464612001016> Accessed: Oct. 15, 2017. doi: 10.1016/j.jff.2012.06.006.

RANADHEERA et al. Microencapulation of Lactobacillus acidophilus LA-5, Bifidobacterium animalis subsp. Lactis BB12 and Propionibacterium jansenii 702 by spray drying in goast's milk. Small Ruminant Research, v. 123, p. 155-159, 2015. Available from: $<$ https://www.sciencedirect.com/science/ article/pii/S0921448814003058>. Accessed: Apr. 11, 2018. doi: 10.1016/j.smallrumres.2014.10.012.

RANADHEERA et al. Probiotic delivery through fermentation: dairy vs. non-dairy everages. Fermentation, v. 3. p. 1-17, 2017. Available from: <http://www.mdpi.com/2311-5637/3/4/67>. Accessed: Apr. 11, 2018. doi: 10.3390/fermentation3040067.

RIVEROS, B. et al. Spray drying of a vaginal probiotic strain of Lactobacillus. Drying Technology, v. 27, p. 123-132, 2009. Available from: <http://www.tandfonline.com/doi/ abs/10.1080/07373930802566002>. Accessed: Nov. 16, 2017. doi: $10.1080 / 07373930802566002$.

SHEU, T. Y.; et al. Improving survival of culture bacteria in frozen desserts by microentrapment. Journal of Dairy Science, v. 76, p.1902-1907, 1993. Avaliable from: <https://www.ncbi.nlm.nih. gov/pubmed $/ 8345127>$. Accessed: Nov. 11, 2017. doi: 10.3168/ jds.S0022-0302(93)77523-2.

SIMPSON, P. J. et al. Intrinsic tolerance of Bifidobacterium species to heat and oxygen and survival following spray drying and storage. Journal of Applied Microbiology, v. 99, p. 493-501, 2005. Available from: < https://www.ncbi.nlm.nih.gov/pubmed/16108790>. Accessed: Dec. 09, 2017. doi: 10.1111/j.1365-2672.2005.02648.x.

TALWALKAR, A. et al. Effect of packaging materials and dissolved oxygen on the survival of probiotic bacteria in yoghurt. International Journal of Food Science and Technology, v. 39, p. $605-611,2004$. Available from: $<$ http://onlinelibrary.wiley.com/ doi/10.1111/j.1365-2621.2004.00820.x/abstract>. Accessed: Oct. 12, 2017. doi. 10.1111/j.1365-2621.2004.00820.x.

VESTERLUND, S. et al. Water activity in dry foods containing live probiotic bacteria should be carefully considered: A case study with Lactobacillus rhamnosus GG in flaxseed. International Journal of Food Microbiology, v. 157, p. 319-321, 2012. Available from: <https:/www.ncbi.nlm.nih.gov/pubmed/22663981>. Accessed: Dec. 22, 2017. doi: 10.1016/j.ijfoodmicro.2012.05.016.

ZHANG, Y.; LIN, J. B.; ZHONG, Q. The increased viability of probiotic Lactobacillus salivarius NRRL B-30514 encapsulated in emulsions with multiple lipid-protein-pectin layers. Food Research International, v. 71, p. 9-15, 2015. Available from: <https:// www.sciencedirect.com/science/article/pii/S0963996915000782>. Accessed: Nov. 01, 2017. doi: 10.1016/j.foodres.2015.02.017. 